\title{
Corporate Governance and Firm Profitability: Evidence from Turkey
}

\author{
Hülya Cengiz
}

\begin{abstract}
Companies that are listed in Borsa Istanbul, can be included in the Corporate Governance Index if their corporate governance rating is within the range of 7 to 10 . Companies can be rated in accordance with their compliance with the corporate governance principles. The aims of the present study are to investigate (i) the performances of the listed companies in the Corporate Governance Index differ from other companies listed in the Borsa Istanbul-100 Index, and (ii) whether there is a relationship between performance and the value of the corporate governance rating for the companies listed in the Corporate Governance Index Financial ratios were used to calculate the performance of companies. The results showed that the companies that are in the corporate governance index have statistically significantly higher return on assets, net profit margin, and return on equity than the ones that are not indexed. Besides, the companies with higher corporate governance rate, have a statistically significantly higher market book value, and return on equity compared to the ones with lower corporate governance rate. These results may instruct potential/current investors and shareholders. However, there is no found evidence regarding the earnings per share which can affect the investment decision shareholders.
\end{abstract}

Index Terms-Borsa Istanbul, corporate governance index, corporate governance rate, financial performance.

\section{INTRODUCTION}

Corporate governance has been a subject of many studies after the scandal of fraudulent financial reporting. In Turkey majority of listed companies were ultimately owned and controlled by families. About 43 percent of the 218 sample companies exhibited deviations from the one share-one vote rule [1] Many countries issued principles of corporate governance to facilitate companies to improve their corporate governance. In Turkey, corporate governance principles were issued by Capital Markets Board of Turkey (CMB) in 2003, and amended in 2011. The principles were prepared in accordance with the Organization for Economic Co-operation and Development (OECD) principles for public companies. The listed companies can adopt these principles voluntarily. However, they have to report any adoption of the corporate governance principles. The corporate governance principles consist of four main sections that are shareholders, public disclosure and transparency, stakeholders and board of directors [2]. On the other hand, Borsa Istanbul (BIST), the stock market of Turkey, is founded on the basis of Capital Markets Board Law for the purpose of serving as a securities exchange. BIST Corporate Governance Index (XKURY) is one of the indices on BIST. XKURY has been indexed since 2007. Companies listed in the BIST with an overall corporate

Manuscript received April 5, 2016; revised December 17, 2016.

Hülya Cengiz is with Yildiz Technical University, 34349 Istanbul, Turkey (e-mail: hucengiz@yildiz.edu.tr). governance rating of a minimum of 7 over 10 while having at least of 6.5 over 10 in each main section, can be indexed in XKURY [3]. The corporate governance rating of a company is determined according to its compliance with the corporate governance principles by rating agencies that are licensed by the Capital Market Board [3].

The efficiency of corporate governance has been studied in emerging markets based on the countries' legal system, market valuation and higher operating performance that was measured by the return on assets [4], [5]. Drobetz et al. [6] reported a significant relationship between corporate governance rating and market-to-book ratio. Gompers et al. [7] reported an association between corporate governance index and company value during the 1990s. After that study, many authors reported a positive relation between corporate governance and operating performance of companies [8]-[10]. Additionally, the questionnaire was conducted to measure the relationship between firm performance and corporate governance [11]. It was found a positive association between corporate governance and various measures of performance that were operating performance, market valuation, and stock returns.

The effects of corporate governance on the performance of companies in Turkey were studied previously. Gürbüz et al. [12] investigated whether the corporate governance practices of the companies lead to better financial performance. Corporate governance practices were measured by institutional ownership, distinguishing between domestic and foreign ownership which are listed in the Corporate Governance Index. . Positive significant relation were found between corporate governance rates that were rated by the quoted rating companies and net income, and shareholder equity for the years of 2006 to 2010 using a price model [13]. The sub-components of corporate governance that have a positive association to the financial performance are stakeholders, and public disclosure and transparency [13]. On the contrary, Çakırc1 et al. [14] reported that the corporate governance and the performance of companies were not in relation comparing with the volatility of listed companies on BIST 100 Index and XKURY. Sengur [15] found no significant difference in performance measures of Corporate Governance Index Companies and 36 companies that listed in BIST for the year of 2010. In this study, return on assets was designated as an accounting based performance measure and Tobin's Q was determined as market based performance measure of companies. Previous studies measured the performance of companies by institutional ownership, distinguishing between domestic and foreign ownership [12]; or by stock return and volatility [14]. In this study, five financial ratios that are return on assets, earnings per share, net profit margin, return on equity and market book value, were used measure the performance of the companies. The aim of the present study is to examine whether the performance of listed companies in the Corporate 
Governance Index differs from other companies listed in BIST 100 and whether the value of the corporate governance rating affects the company performance.

\section{Methodology}

In this study, the financial performances of the companies in Turkey that are listed in the Corporate Governance Index were statistically analyzed to find out if: (i) there are any significant differences between the financial performances of the companies that are listed in the Corporate Governance Index and the ones that are not, and (ii) there are any significant correlation between the financial performances of the companies and the corporate governance ratings for the companies that are listed in the Corporate Governance Index.

There were 44 companies in the Corporate Governance Index in 2012. The number of companies is given according to the value of the corporate governance rating and which are banking sector or not (Table I). In this study, five performance indicating financial ratios have been used:

- Return on Assets \%

- Earnings per Share
- Net Profit Margin

- Return on Equity \%

- Market Book Value

The financial ratios of the companies listed in the Borsa Istanbul are constituted from financial reports, which were announced to the public. Moerover, the corporate governance ratings of the companies were constituted from the financial reports. Table II shows our research hypotheses and sub-hypotheses.

TABLE I: NUMBER OF CATEGORIZED COMPANIES IN THE CORPORATE GOVERNANCE INDEX-2012

\begin{tabular}{llc}
\hline \hline Category & \multicolumn{1}{c}{$\begin{array}{c}\text { Number of } \\
\text { Companies }\end{array}$} \\
\hline $\begin{array}{l}\text { Companies excluding } \\
\text { banking sector }\end{array}$ & $\begin{array}{l}\text { above the average of the } \\
\text { corporate governance ratings } \\
\text { below the average of the } \\
\text { corporate governance ratings } \\
\text { above the average of the } \\
\text { corporate governance ratings } \\
\text { below the average of the } \\
\text { corporate governance ratings }\end{array}$ & 6 \\
\hline Total & & 24 \\
\hline \hline
\end{tabular}

TABLE II: HYPOTHESES AND SUB-HYPOTHESES OF THE T-TEST IN THE ANALYSIS

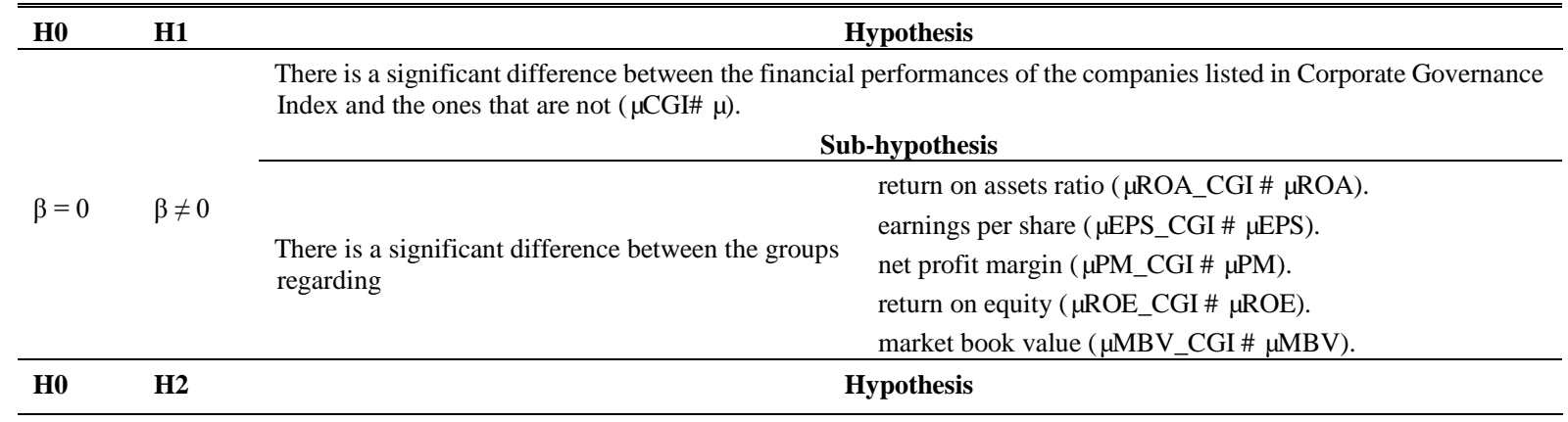

There is a significant difference between the financial performances of the companies which have higher corporate governance ratings and the ones that have lower ( $\mu$ CGR+\# $\mu$ CGR-)

Sub-hypothesis

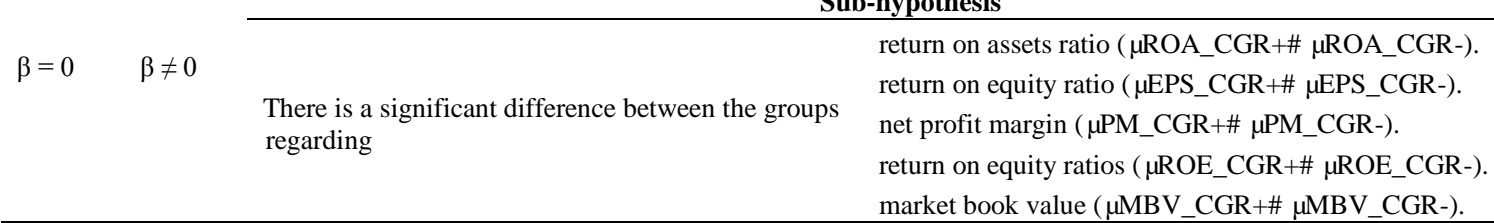

The explanatory variables are Return on Assets (ROA), Earnings per Share (EPS), Net Profit Margin (PM), Return on Equity (ROE), and Market Book Value (MBV).

Significant differences between the groups were statistically tested with t-test and Mann-Whitney U tests. Independent sample t-tests were used when the data is a normal distribution, while Mann-Whitney $U$ tests were used when the sample size is small and unknown distribution an alternative to the t-test.

\section{RESULTS AND DISCUSSION}

Table III summarizes the differences between the financial performances of the companies that are listed in the Corporate Governance Index and the ones that are not. There were differences in return on assets $(\mu \mathrm{ROA} C \mathrm{CGI}=7.40>$ $\mu \mathrm{ROA}=2.62$ ) with $95 \%$ confidence level, in net profit margin ( $\mu$ PM_CGI $=23.85>\mu \mathrm{PM}=6.14$ ) with $90 \%$ confidence level, and in return on equity ( $\mu$ ROE_CGI = $16.50>\mu \mathrm{ROE}=9.93$ ) with $95 \%$ confidence level. Return on assets, net profit margin, and return on equity were higher for the companies that were listed in the Corporate Governance Index. On the other hand, there were no significant differences between the groups in earnings per share and market book value.

Table IV shows the differences between the financial performances of companies and the value of the corporate governance ratings for the companies listed in the Corporate Governance Index excluding banking sector. There were significant differences between the groups in market book value ( $\left.\mu \mathrm{MBV} \_C G R+=2.291>\mu \mathrm{MBV} \_\mathrm{CGR}-=1.136\right)$ with $99 \%$ confidence level and return on equity ( $\mu$ ROE_CGR+ = $19.070>\mu$ ROE_CGR- $=8.176$ ) with $90 \%$ confidence level. Market book value and return on equity were higher for companies that corporate governance ratings were above the average. On the other hand, there were no significant differences in return on assets and earnings per share. The 
results were determined by using an independent sample t-test and Mann-Whitney U test.

TABLE III: FINANCIAL PERFORMANCES OF THE COMPANIES LISTED IN THE CORPORATE GOVERNANCE INDEX AND THE ONES THAT ARE NOT

\begin{tabular}{|c|c|c|c|c|c|c|c|}
\hline Financial Ratios & $\begin{array}{l}\text { Mean } \\
\text { (index) }\end{array}$ & $\begin{array}{l}\text { Mean } \\
\text { (not index) }\end{array}$ & $\begin{array}{l}\mathrm{p} \\
\text { (T Test) }\end{array}$ & $\begin{array}{l}\mathrm{p} \\
\text { (Mann-Whitney } \\
\mathrm{U})\end{array}$ & $\begin{array}{l}\mathrm{p} \text { (Monte } \\
\text { Carlo-Median) }\end{array}$ & $\begin{array}{l}\mathrm{p} \text { (Monte } \\
\text { Carlo- } \\
\text { Upper) }\end{array}$ & $\begin{array}{l}\mathrm{p} \text { (Monte } \\
\text { Carlo-Lover) }\end{array}$ \\
\hline Return on Assets & 7.40 & 2.62 & 0.08 & $0.036^{*}$ & 0.038 & 0.043 & 0.033 \\
\hline Earnings Per Share & 0.99 & 0.76 & 0.63 & 0.353 & 0.354 & 0.367 & 0.342 \\
\hline Net Profit Margin & 23.85 & 6.14 & 0.19 & $0.087 *$ & 0.086 & 0.093 & 0.078 \\
\hline Return on Equity & 16.50 & 9.93 & 0.11 & $0.016^{*}$ & 0.017 & 0.021 & 0.014 \\
\hline Market Book Value & 2.12 & 2.25 & 0.80 & 0.555 & 0.591 & 0.574 & 0.549 \\
\hline
\end{tabular}

The significant differences are indicated with an asterisk.

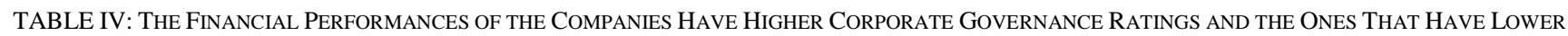
LISTED IN THE CORPORATE GOVERNANCE INDEX EXCLUDING BANKING SECTOR

\begin{tabular}{|c|c|c|c|c|c|c|c|}
\hline Financial Ratios & $\begin{array}{l}\text { Mean } \\
(\mathrm{CGR}+)\end{array}$ & $\begin{array}{l}\text { Mean } \\
\text { (CGR-) }\end{array}$ & $\begin{array}{l}\mathrm{P} \\
(\mathrm{t}-\mathrm{Test})\end{array}$ & $\begin{array}{l}\text { p(Mann-Whitney } \\
\text { U) }\end{array}$ & $\begin{array}{l}\mathrm{p} \text { (Monte } \\
\text { Carlo-Median) }\end{array}$ & $\begin{array}{l}\mathrm{p} \text { (Monte } \\
\text { Carlo- } \\
\text { Upper) }\end{array}$ & $\begin{array}{l}\mathrm{p} \text { (Monte } \\
\text { Carlo-Lover) }\end{array}$ \\
\hline Return on Assets & 8.345 & 4.946 & 0.231 & 0.248 & 0.273 & 0.285 & 0.262 \\
\hline Earnings per Share & 1.296 & 0.316 & 0.235 & 0.126 & 0.135 & 0.143 & 0.126 \\
\hline Net Profit Margin & 12.696 & 64.190 & 0.439 & 0.686 & 0.724 & 0.736 & 0.712 \\
\hline Return on Equity & 19.070 & 8.176 & $0.073 *$ & $0.065^{*}$ & 0.074 & 0.081 & 0.067 \\
\hline Market Book Value & 2.291 & 1.136 & $0.001 *$ & $0.033 *$ & 0.032 & 0.037 & 0.028 \\
\hline
\end{tabular}

The significant differences are indicated with an asterisk. The explanatory symbols show higher corporate governance ratings (CGR+), lower corporate governance ratings (CGR-)

TABLE V: THE FinANCIAL PERFORMANCES OF COMPANIES HAVE Higher CORPORATE GOVERNANCE RATINGS AND THE ONES THAT HAVE LOWER LiSTED IN THE CORPORATE GOVERNANCE INDEX INCLUDING BANKING SECTOR.

\begin{tabular}{lllllll}
\hline \hline Financial Ratios & $\begin{array}{l}\text { Mean } \\
(\mathrm{CGR}+)\end{array}$ & $\begin{array}{l}\text { Mean } \\
\text { (CGR-) }\end{array}$ & $\begin{array}{l}\mathrm{p} \\
(\mathrm{t} \text {-Test) }\end{array}$ & $\begin{array}{l}\mathrm{p} \text { (Mann-Whitney } \\
\mathrm{U})\end{array}$ & $\begin{array}{l}\mathrm{p} \text { (Monte } \\
\text { Carlo-Median) }\end{array}$ & $\begin{array}{l}\mathrm{p} \text { (Monte Carlo- } \\
\text { Upper) }\end{array}$ \\
\hline Return on Assets & 2.7508 & 1.3050 & 0.365 & 0.144 & 0.191 & 0.201 \\
EPS & 0.3608 & 0.5900 & 0.601 & 0.410 & 0.482 & 0.495 \\
Return on Equity & 11.3375 & 17.6150 & 0.188 & 0.201 & 0.262 & 0.273 \\
Market Book Value & 1.0133 & 1.3900 & 0.177 & 0.144 & 0.197 & 0.469 \\
\hline \hline
\end{tabular}

The explanatory symbols are higher corporate governance ratings (CGR+), lower corporate governance ratings (CGR-).

Table V summarizes the differences between the financial performances of the companies and the value of the corporate governance ratings for the companies that were listed in the Corporate Governance Index including banking sector. There were statistically insignificant differences in return on assets, earnings per share, net profit margin, return on equity and market book value by using t-test and Mann-Whitney U test.

\section{CONCLUSION}

This study showed that the companies that are listed in the Corporate Governance Index in Turkey have statistically significant higher financial performances in terms of return on assets, net profit margin, and return on equity compared to the companies that are not listed. Additionally, the companies with higher corporate governance rating have statistically significant higher performances regarding market book value and return on equity, in respect to the ones with lower corporate governance rate. These results indicate that efficient adoption of corporate governance principles provides higher financial performances. The general belief in shareholders and potential investors, earnings per share is important; in contrast, there is no statistical evidence in the analysis. On the other hand, return on assets, net profit margin, and return on equity are essential to determine the financial performances of companies that are listed in the Corporate Governance Index, while there is no statistically significant difference in earnings per share and market book value.

\section{REFERENCES}

[1] H. Orbay and B. B. Yurtoglu, "The impact of corporate governance structures on the corporate investment performance in Turkey," Corporate Governance: An international Review, vol. 14, no. 4, pp. 349-363, 2006.

[2] Capital markets board of Turkey. (Jan. 20, 2016). [Online]. Available: www.cmb.gov.tr/

[3] Borsa Istanbul. (2015). [Online]. Available: http://www.borsaistanbul.com/

[4] A. L. C. Da Silva and R. P. C. Leal, "Corporate governance index, firm valuation and performance in Brazil," Brazilian Review of Finance, vol. 3, no. 1, pp. 1-18, 2005.

[5] L. F. Klapper and I. Love, "Corporate governance, investor protection, and performance in emerging markets," Journal of Corporate Finance, vol. 10, no. 5, pp. 703-728, 2004.

[6] W. Drobetz, A. Schillhofer, and H. Zimmermann. (2003). Corporate governance and firm performance: Evidence from Germany. Basel, Switzerland: University of Basel. Mimeographed document. [Online]. Available:

http://www.cofar.uni-mainz.de/dgf2003/paper/paper146.pdf

[7] P. A. Gompers, J. L. Ishii, and A. Metrick, Corporate Governance and Equity Prices, National Bureau of Economic Research, 2001.

[8] B. Black, "The corporate governance behavior and market value of Russian firms," Emerging Markets Review, vol. 2, no. 2, pp. 89-108, 2001.

[9] U. Garay and M. González, "Corporate governance and firm value: The case of Venezuela," Corporate Governance: An International Review, vol. 16, no. 3, pp. 194-209, 2008.

[10] P. Varshney, V. K. Kaul, and V. Vasal, "Corporate governance index and firm performance: Empirical evidence from India,” 2012.

[11] I. Love, "Corporate governance and performance around the world: What we know and what we don't," The World Bank Research Observer, p. 1kp030, 2010. 
[12] A. O. Gürbüz, A. Aybars, and Ö. Kutlu, "Corporate governance and financial performance with a perspective on institutional ownership: Empirical evidence from Turkey," Journal of Applied Management Accounting Research, vol. 8, no. 2, p. 21, 2010.

[13] E. Ergin, "Corporate governance ratings and market-based financial performance: Evidence from Turkey," International Journal of Economics and Finance, vol. 4, no. 9, p. 61, 2012.

[14] İ. H. Çakırcı, Ş. Kalaycı, and İ. Y. Gök, "Kurumsal Yönetim-Şirket Performansı İlişkisi: İMKB Kurumsal Yönetim Endeksi Üzerine Ampirik Bir Çalışma," Uluslararası Alanya İşletme Fakültesi Dergisi, vol. 1, no. 1, 2009.

[15] E. D. Sengur, "Do corporate governance index companies outperform others?: Evidence from Turkey," International Journal of Business and Social Science, vol. 2, no. 14, 2011.

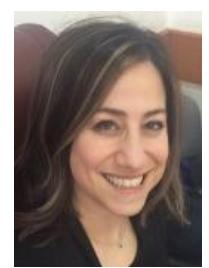

Hülya Cengiz was born in Istanbul, Turkey. She obtained her Ph.D. degree from Istanbul University in Turkey. She has been working at Yildiz Technical University in Turkey since 2003. Her research interests include financial reporting, International Financial Reporting Standards, IFRS for Small and Medium-Sized Entities, corporate governance, financial structure and financial ratios. 